\title{
Salvific Luck in Islamic Theology
}

\author{
Amir Saemi \\ Institute for Research in Fundamental Sciences (IPM) \\ Tehran Iran \\ Scott A. Davison \\ Morehead State University \\ Morehead KY USA
}

\begin{abstract}
One of the major arguments for theological voluntarism offered by the Ash'arites (e.g. al-Ghazali) involves the claim that that some of the factors upon which our salvation or condemnation depend are beyond our control. We will call this "the problem of salvific luck." According to the Ash'arites, the fact that God does save and condemn human beings on the basis of factors beyond their control casts doubt on any non-voluntarist conception of divine justice. A common way to respond to this Ash'arite argument for voluntarism is to eliminate the role of luck in God's judgments. But this is not the Mu'tazilite way of resisting the argument. The Mu'tazilite, who oppose theological voluntarism, choose a more daunting solution to the problem of salvific luck. They reject the claim that God's Judgment concerning the eternal destiny of some persons would be unjust (relative to the objective common sensical standard of justice that could not have been different) if it depended upon factors beyond their control. The paper discusses this solution to the problem of salvific luck.
\end{abstract}

Along with many traditional theists, Islamic theologians have typically embraced the following claims:

Divine Compassion: God is perfectly compassionate.

Divine Justice: God is perfectly just.

Divine Judgment: Every human person will survive death and will be judged by God, with the result that some will live eternally in a state of bliss (often called "salvation in Heaven"), and others will live eternally in a state of misery (often called "condemnation in Hell").

Journal of Analytic Theology, Vol. 8, August 2020

10.12978/jat.2020-8.180008030013

(C) 2020 Amir Saemi, Scott A. Davison • (C) 2020 Journal of Analytic Theology 
They have disagreed, however, about the nature of Divine Justice: is God's justice perfect because God conforms perfectly to some independent standard of justice, a standard that could not have been otherwise? Or is God's justice perfect because God chooses the nature of justice itself, where there is no independent standard to which God must conform in order to be just? The Mu'tazilite theologians embraced the former option, according to which God's justice consists in conformity with an independent standard of justice to which we have access by reason, whereas the Ash'arites embraced the latter, according to which God chooses the nature of justice itself, and there is no independent standard to which God must conform. For ease of reference, we will call the Mu'tazilite position "Independence" and the Ash'arite position "Voluntarism."

One of the major arguments for Voluntarism offered by the Ash'arites involves the claim that that some of the factors upon which our salvation or condemnation depend are beyond our control. We will call this "the problem of salvific luck." The Ash'arites argued as follows. We believe that God does, in fact, save and condemn human beings on the basis of factors beyond their control (below we will explore some purported examples of this, in terms of cases that are often described as cases of moral luck). But if this were so and Independence were correct, God would be unjust; but that is absurd. So Voluntarism must be true, and the right account of divine justice must be understood in terms of God's voluntary commands and prohibitions (which are recorded in the religious law).

Why were the Ash'arites so confident that God saves or condemns human beings on the basis of factors that are at least partly beyond their control? The wellknown story of the three brothers illustrates this claim nicely (as told by the famous Ash'arite theologian al-Ghazali):

Observation and reality prove the falsity of the view [of placing moral restrictions on the acts of God]; for we will show them acts of God (Glorious is $\mathrm{He}$ ) that will force them to concede that they do not serve the interest of His servants. Let us suppose that there are three children: one of them dies a Muslim in his youth, another reached maturity, became a Muslim, and died a Muslim in his maturity, and the third became an infidel in his maturity and died while in the state of infidelity. Justice for them requires that the mature infidel reside forever in hellfire, and the mature Muslim have a higher rank in paradise than the Muslim youth. The Muslim youth might say: "O Lord, why did You give me a rank lower than his?" God might say "Because he reached maturity and obeyed me and you did not obey me by performing acts of worship, since you did not reach maturity." He might say "O Lord, You made me die before reaching maturity. My best interest would have been for my life to have been extended until I reached maturity, so that I might have obeyed you and attained his rank; why did You deny me this rank forever, where you were able to make me qualified for it?" God would have no answer but to say: "I knew that if you had reached maturity, you would have sinned rather than obeyed me, and then you would be subject to my punishment and wrath. The infidel might call from the abyss and say "O Lord, did You not know that if I reached maturity, I would be an infidel? Had you made me die in my youth and 
placed me at that low rank in paradise, I would have loved that and it would have been better for me than Your condemning me forever to hellfire; so why did You make me live when death was better for me?" There would be no answer available for God at all (al-Ghazali 2013, 179).

According to a famous anecdote, Al-Ashari, the founder of the Ash'arite school, adopted Voluntarism upon hearing this story. Although the circumstances of one's death are typically beyond one's control (barring cases of suicide etc.), they could contribute to divine judgment regarding one's eternal destiny in some cases making the difference between salvation and condemnation. A late death led to the third brother becoming worse, whereas an early death enabled the first brother to end life as a better person than he would have been had he died later. These are examples of salvific luck. follows:

More explicitly, the Ash'arite argument for Voluntarism can be stated as

P1. Divine Justice: God is perfectly just.

P2. Divine Judgment: Every human person will survive death and will be judged by God on the basis of how they lived their earthly lives, with the result that some will live eternally in a state of bliss (often called "salvation in Heaven"), and others will live eternally in a state of misery (often called "condemnation in Hell").

P3. Creaturely Control: God's Judgment concerning the eternal destiny of some persons depends in part upon factors beyond their control.

P4. If Independence and Creaturely Control (P3) were true, then Divine Justice (P1) would be false.

P5. Therefore, Independence is false.

P6. Either Independence is true or Voluntarism is true.

C. Voluntarism is true.

P1 and P2 are widely accepted in Islamic theology. P5 is also trivially true. So, the major premises of the argument are P3 and P4. The truth of P3 is supposed to be illustrated by the story of three brothers. In the case of three brothers, the circumstances of their death changed their moral and religious characters. One's moral and religious character, arguably, are important grounds for God's Judgment concerning one's eternal destiny. Other circumstantial lucks can also affect one's moral character. The development of one's moral character might depend on one's environment, including available opportunities, affluence, the political conditions, etc. Moreover, there might be other kinds of luck affecting God's Judgment concerning one's eternal destiny. The outcomes of one's actions can be affected by luck. If one's actions are among grounds for God's Judgment, given that the results of one's actions 
are clearly beyond one's control, God's judgment depends on factors beyond one's control.

P4 is based on common sense morality. According to the common sense notion of justice, it would be unjust for God to determine one's eternal destiny based on factors that are beyond one's control. Strictly speaking, Independence does not entail the common sense notion of justice is true. Here we will assume that, if standards of justice are independent of God, they are just those that are specified by the common sense notion of justice. (Debates about the extent and nature of human moral knowledge, assuming independent standards of justice, fall beyond the scope of this paper.) If this is so, then Independence entails that God's judgment concerning the eternal destiny cannot depend on factors beyond their control on pain of God's being unjust. Therefore, as P4 states, Independence and Creaturely Control entail that God is not just.

A common way to respond to this Ash'arite argument for Voluntarism is to deny P3. This solution seeks to eliminate the role of luck in God's judgments. ${ }^{1}$ This would be achieved by somehow limiting the ground of God's judgment to factors that are not susceptible to luck or by stipulating a metaphysics in which God somehow cancels out differences that are due luck. But this is not the Mu'tazilite way of resisting the argument. They choose a more daunting solution by challenging P4. They reject the claim that God's Judgment concerning the eternal destiny of some persons would be unjust (relative to the objective common sensical standard of justice that could not have been different) if it depended upon factors beyond their control. They address this question directly in their discussions of God's grace (lutf).

According to the Mu'tazilites, an instance of God's grace involves God's helping people to act morally through providing rewards and punishments for moral behavior. Eternal rewards and punishments are special cases of grace, and provide especially strong motivations for people to act morally. God helps people to be good by establishing a system of reward and punishments. Moreover, the highest degree of happiness, according to the Mu'tazilites, lies in receiving divine rewards because of one's good conduct. ${ }^{2}$ The assumption here is that the value of receiving rewards because of one's efforts is much higher than the value of receiving some favor of God when one has done nothing to deserve them. So by giving us the opportunity to receive divine rewards because of our deeds, God makes the highest good accessible to us.

But suppose that God knows that someone would turn down the opportunity to earn heavenly rewards by choosing to live a morally bad life. Such a person will live eternally in a state of misery because of God's system of rewards and punishments. How can it be the case, the critic of the Mu'tazilites asks, that God's act of creating rewards and punishment is an instance of God's grace for this person? After all, he

\footnotetext{
1 This solution to the problem of salvific luck has been explored by many contemporary philosophers including Craig (1989), Davison (1999), Anderson (2011), Hartman (2014), and Zagzebsli (1994).

2 The Ash'rites disagree. For example, al-Juwaini, a well-known Ash'rites theologian think that happiness should be understood in terms of pleasure and pain, and the reasons for one's being in the state of pain or pleasure does not affect its value. Therefore, being in heaven because one's good deeds has no more value than just being in heaven (for whatever reason); for more on this, see al-Juwaini 2000.
} 
will live eternally in a state of misery because of this grace, and God knew this in advance. The prominent Mu'tazilite theologian Abd al-Jabbar (936-1025 CE) answers this objection as follows:

The conclusion from all this is that the imposition of moral obligation on the unbeliever is as good as its imposition on the believer. There is no disagreement about this. The only dispute is about how it is good of God to impose moral obligation on one He knows will disbelieve. We say it is good simply because God has raised him to a level which can be reached only with moral responsibility: the level of opportunity for a reward (McDermott 1978, 73).

Abd al-Jabbar provides two examples to illustrate this idea (Abd al-Jabbar $1965,512-513)$. The first example involves a man who throws ropes to save two drowning people, knowing that only one person would accept help by taking hold of a rope. Although the man knew that the other person would refuse his help, he nevertheless offered it - the act of throwing the rope was a gracious act of helping the drowning persons, even if the help was refused by one of them. The second example is about a man who gives food to two people who are starving to death, knowing that one person will eat the food, whereas the other will not, and thus will die. In the same way as before, the man's act of offering food was a gracious act, even if it was refused by the intended recipient.

Abd al-Jabbar's discussion of grace helps us to see why he would reject P4. Compare the second brother and the third brother from the story of the three brothers as described by al-Ghazali. The second brother led a morally decent life, whereas the life of the third brother was morally regrettable. Using Abd al-Jabbar's analogy, the second brother grabbed the rope thrown at him and thus survived, whereas the third brother ignored the rope and thus perished as a result of his own actions. He will live a life of eternal misery, but only because he performed many deplorable acts.

Now compare the third brother to the first brother, who died young. These two brothers had very different lives, morally speaking. The first brother did not perform the same morally wrong actions that the third brother did. In fact, the life of the first brother was not morally deplorable at all; it would have been, had he not died young, but in fact, it was not. The third brother deserves punishment for what he has done. The first brother does not deserve punishment for what he has done. Of course, it is true that the first brother was lucky to die young. But this does not change the fact that he did not deserve punishments for his actual deeds, while the third brother did. Therefore, Abd al-Jabbar would say, P4 is false. It can be perfectly just to condemn persons to live eternally in a state of misery (in part) because of factors beyond their control. There is salvific luck, but it is compatible with Divine Justice, even if Independence is true.

However, the claim that salvific luck is compatible with Divine Justice strikes some as implausible. Perhaps the idea behind the claim that salvific luck is incompatible with Divine Justice is expressed adequately by the following claim: 
Desert \& Control: Just rewards and punishments supervene on internal psychological states over which agents have intentional control.

This claim is consistent with the idea that the third brother deserves punishment, whereas the first brother does not-presumably, they had different internal psychological states, due to the fact that they had very different life spans. In general, when differences between persons are due to circumstantial luck, the persons in question have different internal psychological states and hence act differently. So, the claim that salvific luck is incompatible with Divine Justice in cases of circumstantial luck should perhaps be expressed by claims that use counterfactual comparisons. Such claims would be stronger than Desert \& Control. However, there are other alleged examples of moral luck which conflict even with Desert \& Control. In those examples, two agents are identical with respect to internal psychological states, yet quite different morally (see Nagel 1979, most famously); we might think of these kinds of cases as cases that involve salvific luck also.

For instance, suppose Joan decides to drive drunk and runs over a child and because of this (in part), she will live eternally in a state of misery. Suppose also that Joan's counterpart Joan*, who is identical to Joan with respect to internal psychological states, drives drunk in very similar circumstance, but because no child happens to be crossing the street at the time, she does not run over any child. Let us suppose that because of this (in part), Joan* will not live eternally in a state of misery. If we assume that one's actions are among the grounds of God's final Judgement, this seems inconsistent with Desert \& Control. One way to retain Desert \& Control is to deny that one's actions are among the grounds of God's final judgment-perhaps, for example, God considers only character, intentions, and internal psychological states, not actions. But should we accept Desert \& Control in the first place? The Mu'tazilite take the more challenging route of denying Desert \& Control altogether. They argue that whereas just rewards may supervene on internal states that are within one's intentional control, just punishments are different.

Contemporary support for the Mu'tazilite approach can be found in discussions of different kinds of luck. For example, Ronald Dworkin distinguishes option luck from brute luck. "Option luck is a matter of how deliberate and calculated gambles turn out-whether someone gains or loses through accepting an isolated risk he or she should have anticipated and might have declined" (Dworkin 2000, 73). By contrast, brute luck is "a matter of how risks fall out that are not in that sense deliberate gambles" (Dworkin 2000, 73). Dworkin argues that justice is consistent with inequalities that result from option luck, so that the state is not required to compensate individuals for the differences between persons that result from it.

The same can be true in a system of rewards and punishments. Consider an example of option luck involving prudential cost. Precisely because of option luck, it does not seem to be the case that the imposition of prudential costs is just only if such costs supervene on internal states within one's intentional control. Suppose Maya spends some of her money to buy a lottery ticket but does not win. Her not winning was not under her intentional control, but this does not mean that the prudential cost imposed on her was unjust. Imagine Maya*, the counterpart of Maya, who buys a ticket and wins the lottery. The lottery prize is substantially higher than the price of 
the ticket, so it turns out that Maya*'s net prudential cost was negative, and not positive. While Maya and Maya* are identical with respect to the internal psychological states over which they have intentional control, their situations are different with respect to net imposed prudential costs. But imposing different net prudential costs on them does not seem to be unjust. Therefore, it is not the case that imposing prudential costs are just only if they supervene on internal psychological states over which one has intentional control.

Perhaps we can say the same thing about moral punishment. Joan made the morally wrong choice of driving while she was drunk. That choice becomes very costly for her, morally speaking. She killed a child; she deserves to be punished. Joan* also made a wrong choice, but she was lucky that the action had no morally significant consequences. But just because Joan* did not pay the same moral cost for her choice, it does not follow that it is unjust for Joan to pay a heavier moral cost, in the same way that it was not unjust that Maya should pay some net prudential cost for entering the lottery even though Maya* did not. Joan undertook a moral gamble and lost it; she is in no position to object to the moral result. Joan can't complain about Joan*'s not suffering the same fate, in the same way that Maya cannot complain about Maya*'s winning the lottery. It was not unfair to Maya that Maya* did not lose the lottery. Similarly, it is not unfair to Joan that Joan* did not lose the moral gamble.

One might object here that there is an important difference between the lottery and God's punitive system: the process of the lottery is blind, whereas God has the power to pick winners and losers. It is up to God, one might say, whether Joan runs over the child and Joan* does not. But it is not just for God to pick Joan* over Joan, or so one might object. However, it might be the case that God creates a natural order of events, perhaps involving randomness, and for a number of reasons, God does not often intervene in it. Joan has no ground to object to God's not intervening in the course of events if there are good reasons against this. If God has good reasons not to intervene in the natural order, and if it also contains randomness, then there will be random winners and losers, and losers would have no ground to object to the fact that there are others in comparable situations who do not lose.

So it seems that different moral and prudential costs, resulting from option luck, are consistent with Divine Justice. What is not consistent with Divine Justice is the differential effects of sheer brute luck. But notice that in none of the cases we have discussed is God's judgment based on sheer brute luck. Of course, the circumstance of one's death is a case of brute luck. But God's Judgment about the three brothers are not based on the circumstance of their deaths alone-instead, they have different destinies because they took morally different paths in life and performed significantly different actions.

Here one might object instead that salvific luck presents a problem for Divine Compassion. Even though Abd al-Jabbar says that God helped the third brother by giving him the opportunity to have the highest degree of happiness, it would have been compassionate also for God to let the third brother die earlier so that he would avoid a life of eternal misery. Interestingly, Abd al-Jabbar has some sympathy for this claim. Even though, on his view, the third brother is a recipient of God's grace, he 
acknowledges that the third brother would have been better off had he died earlier, and thus God did not actually do what was best for him:

And it is known that He is better at looking after His servants than they are for themselves in what pertains to religion and moral obligation. This restriction must be made because God punishes the disobedient, whereas if they were given a choice in the matter they would not choose the punishment for themselves. So, this being the case, God is not better at looking after their interests than they are for themselves. Thus He may prolong the life of a man even though He knows that, should He have him die then and there, he would deserve the Garden on account of his previous deeds, and if He keeps him alive he will apostatize, disbelieve, and render void all that he has previously merited. And obviously if the man were given the choice between longer life and early death, he would choose early death. So how is God in this case better at looking after His servants than they are for themselves? Therefore the restriction we have mentioned is necessary. (McDermott 1978, pp.74-75)

In the passage, Abd al-Jabbar acknowledges that what happens to the third brother is not in his best interest. He himself would not have chosen this, had he been given a choice. But why wouldn't a compassionate God do what is best for the third brother? Abd al-Jabbar's answer to the problem is not very clear. He says that what God did for the third brother was the best thing He could do for him with respect to "what pertains to religion and moral obligation." Perhaps the idea is that God's goal is to create a system of religion and morality in which human beings can achieve the highest good through moral conduct. There might be necessary costs to this system, though; for instance, it might be that some people will experience a life of misery as a result of this system, and perhaps God could not prevent this (on the assumption that God wants to create a universe in which the highest good is possible for human beings). But these costs would not be problematic if they do not involve injustice and there is no better alternative. So perhaps God's treatment of the third brother is justifiable if it meets the following three conditions: (1) The highest good is possible for him; (2) his punishment is not unjust; (3) there is no alternative arrangement which (a) makes the highest happiness possible for human beings in general and (b) involves less misery for the third brother.

But what about the first brother? The situation of the first brother might appear to be problematic in two respects: First, he does not deserve salvation in Heaven at all, and second, the highest good was not possible for him. Let's take up these issues in order.

Regarding the first point, one might think that just rewards supervene on internal states that are within one's intentional control. Neither Joan nor Joan* deserved to be off the hook, morally speaking. Neither Maya nor Maya* deserved to win the lottery. In the same vein, the first brother has done nothing to deserve salvation in Heaven. If so, one might think that it would be unfair for God to favor Joan* over Joan, and in the same way, to favor the first brother over the third brother. In other words, if the winner does not deserve to win, why should she enjoy a better life? 
It seems that the Mu'tazilites would accept the claim that deserved rewards supervene on internal states that are within one's intentional control. They would also hold that Joan*, Maya* and the first brother do not deserve the benefits bestowed upon them. However, they would say that from the fact that a benefit is undeserved, it does not follow that the bestowing of it is unjust-it would not be unjust for God to give undeserved rewards. It is important to remember that Joan deserves blame for running over the child, and the third brother deserves blame for his bad conduct. The fact that Joan* does not deserve any credit is of no help to Joan, since she deserves to be blamed. Now suppose that it is not possible to help Joan and Joan* at the same time, and not possible to help the first brother and the third brother at the same time, without preventing some equally important good thing. It would not be unjust for God to distribute the goods among people unevenly if an even distribution is not possible. Divine Compassion is not contradicted by an uneven distribution if an even distribution is not possible. And the losers, such as Joan and the third brother, have no ground to object to God if there is nothing unjust here.

The second point raised above was that the highest possible good was not offered to the first brother, and one might find this to be an objectionable aspect of Abd al-Jabbar's view. It seems clear, though, that he would think of this as an instance of the problem of evil. According to Abd al-Jabbar, God's allowing a person to suffer is justified if the two following conditions are met: (a) The person is compensated in the afterlife to the degree that she would rationally prefer receiving the compensation and the suffering, as opposed to not having the suffering in the first place; (b) the suffering serves a moral point in the grand scheme of the universe, a point that could not have been achieved had God not allowed the suffering (see Heemskerk 2000). The same can be said about the first brother: God compensated the first brother disproportionately, and his early death was perhaps necessary for "what pertains to religion and moral obligation." These two conditions justify the fact that he was not offered the opportunity to achieve the highest possible happiness.

In conclusion, we noted that there are two major ways to resist the Ash'arite argument for Voluntarism. One way is to accept P4 but to deny P3. The other way is to accept P3 but to deny P4. The first way, which is rather popular among contemporary philosophers, and which we did not discuss in this paper, is roughly based on the idea of limiting the grounds of God's judgment to those factors that are not susceptible to luck. For example, if we exclude one's actions from the grounds of God's judgment, then the difference between Joan and Joan* are not relevant for God's Judgment. But, of course, Joan's and Joan*'s actions may have further consequences on their later characters and internal psychological states. Moreover, other kinds of circumstantial luck, including one's death and one's environment, can also affect one's character and internal psychological states. So, the idea would be to limit the grounds of God's judgments to some deep internal psychological states that are stable enough across counterfactual scenarios not to be affected by luck. The challenge for this solution is, first, to find meaningful deep counterfactually stable internal states, and, second, to justify the claim that God's moral and religious assessment should be based on those factors alone. The Mu'tazilites go the opposite way. On their view, the ground of God's judgment includes everything that looks morally and religiously relevant, 
including one's actions, beliefs, etc. But then they argue that the susceptibility of those factors to luck poses no problem for Divine Justice and Divine Compassion. We conclude that the Mu'tazilite approach to salvific luck is not obviously mistaken. ${ }^{3}$

\footnotetext{
${ }^{3}$ We are thankful to Kelly Clark, Jeff Koperski, Aaron Griffith, Yamina Bouguenaya, and Samuel Lebens for their very helpful comments on an earlier draft of the paper. We also gratefully acknowledge the generous support of the John Templeton Foundation's “Models of Providence" grant.
} 


\section{References}

Uthman, Abd al-Karim (editor). 1965. Sharh al-usul al-khamsa by WahbaAbd alJabbar b. Ahmad b. Abd al-Jabbar al-Hamadhani. Wahba Publishing.

Al-Ghazali, Abu Hamid M. b. M. 2013. Moderation in Belief. Translated by Yaqub, Aladdin M. Universty of Chicago Press.

'al-Juwaynī, Abd al-Malik. 2000. A Guide to Conclusive Proofs for the Principles of Belief. Translated by Paul Walker. Garnet Publishing.

Anderson, Mark B. 2011. "Molinism, Open Theism, and Soteriological Luck." Religious Studies 47 (3): 371-81. September 2011.

Craig, William Lane. 1989. “'No Other Name': A Middle Knowledge Perspective on the Exclusivity of Salvation through Christ." Faith and Philosophy 6 (2): 172-188.

Davison, Scott A. 1999. "Salvific Luck.” International Journal for Philosophy of Religion 45 (2):129-137.

Dworkin, Ronald. 2000. Sovereign Virtue. Harvard University Press.

Hartman, Robert J. 2014. "How to Apply Molinism to the Theological Problem of Moral Luck." Faith and Philosophy 31 (1):68-90.

Heemskerk, Margaretha, T. 2000.Suffering in the Mu'tazilite Theology: 'Abd AlJabbār's Teaching on Pain and Divine Justice (volume 41). Brill publishing company.

McDermott, Martin J. 1978. Theology of al-Shaikh al-Mufid. Dar el-Machreq Editeurs.

Nagel, Thomas. 1979. "Moral Luck." In Mortal Questions, edited by Thomas Nagel. Cambridge University Press.

Zagzebski, Linda. 1994. “Religious Luck.” Faith and Philosophy 11 (3):397-413. 